\title{
Greek Economy: 1950 - 2014: The 30 Year Road Leading to the Greek Financial Crisis and the IMF-EU-ECB Bail-Out: Investments and Exports Are the Way Out
}

\author{
John Chalikias ${ }^{1}$
}

\begin{abstract}
:
Up until the 1970s, Greece was a paradigm of a vigorous economy with high growth rates, positive budgets and low borrowing. Even when the international economy experienced a recession in the 1970s on account of the oil crisis, the Greek economy continued to grow. In the 1980s an imprudent fiscal policy mix (involving higher pensions, higher salaries to civil servants, early retirements, overcrowding the civil service and loss-making state-owned enterprises trough new hires, etc.) produced large deficits which, in turn, lead to increased borrowing as the economy's growth rate slowed down. The rest of the story is pretty much known. As the country's creditworthiness declined it became harder to obtain the funds needed and Greece turned to its lenders of last resort (IMF, EU and ECD), referred to as the troika. Harsh steps were taken, which involved wage and pension cuts, which, in turn, adversely affected consumption, making the recession inevitable. It is a problem with a straightforward solution: Increase exports and investments. In this paper we demonstrate the beneficial impact of these two variables, exports and investments, on the economy, and present alternative scenarios regarding the evolution of these factors and their impact on the GDP.
\end{abstract}

Key Words: GDP, growth, investments, exports

\footnotetext{
${ }^{1}$ Athens University of Economics and Business \& Exports Research Centre of the PanHellenic Exporters Association

Note: An earlier version of this paper appeared in Greek Economic Outlook, Centre of Planning and Economic Research, Issue 22, October 2013.
} 


\section{Introduction}

Up until the 1970s, Greece was a paradigm of a vigorous economy: Growth rates were high (5-8\%), borrowing was low (less than 20\% of the Gross Domestic Product (GDP), government budgets run either at a surplus or at small deficit. Even when the international economy experienced a recession in the 1970s on account of the oil crisis, the Greek economy continued to grow (with the exception of 1974, a year marked by political instability and the Turkish invasion of Cyprus). It was by and large for these high growth rates that Greece was accepted in the European Economic Union.

In the 1980s an imprudent fiscal policy mix (involving higher pensions, higher salaries to civil servants, early retirements, overcrowding the civil service and lossmaking state-owned enterprises trough new hires, etc.) produced large deficits which, in turn, lead to increased borrowing (reaching 120\% of the GDP by the mid1990s) as the economy's growth rate slowed down. Between 1995 and 2007, attempts were made to reverse the situation. The relative improvement in a number of areas and economic indicators allowed Greece to enter the Eurozone in 2002 (Thalassinos, Liapis 2013; Thalassinos et al., 2007; Thalassinos et al., 2012).

However, to the extent that growth depended almost exclusively on consumption (over 90\%), the situation was not sustainable. The advent of the international financial and economic crises in 2008-9 lead things to a head: consumption plummeted, incomes (output) and state revenues followed, deficit borrowing rose, and the debt-to-GDP ratio escalated.

The rest of the story is pretty much known. As the country's creditworthiness declined it became harder and to obtain the funds needed. So Greece turned to its lenders of last resort, the International Monetary Fund (IMF), the European Union (EU) and the European Central Bank (ECD), frequently referred to as the troika. To secure the bailout package, Greece had to guarantee (via a memorandum of understanding) to become again a reliable borrower. That is, to gradually bring the deficit down and return to surplus, for it is only then that borrowing will stop. So, harsh steps were taken, steps that any technocrat would recommend. They involved wage and pension cuts, which, in turn, adversely affected consumption, making the recession inevitable. To recap: Our consumption-based economy was not viable.

While fueling growth for a long time, it also fed the deficit. Now that borrowing is cut, for no one lends us money just to spend it on consumption, consumption is shrinking, so GDP is shrinking too. Consequently, we are faced with a recession.

It is a problem with a straightforward solution: Increase exports and investments. Both are GDP components. Investments in particular, beyond positively affecting exports, may also stimulate consumption (which lately relied on borrowing). 
The combined effect ought to bring us back to a sustainable growth path. Back in the 1970s, when we had a vigorous economy, investments were more than half of consumption; in 2009 a mere one sixth of it.

In the pages that follow we will demonstrate the beneficial impact of these two variables, exports and investments, on the economy, and present alternative scenarios regarding the evolution of these factors and their impact on the GDP.

\section{The fundamental variables of the Greek economy: 1950 - 2014}

Charts 1, 2 and 3 track the evolution of real GDP, as well as the government's debt and deficit compared to the GDP. The healthy economic outlook of the period 19601980, was succeeded by a drastic deterioration running from 1980 to our days. Note that while the GDP increased almost six fold during 1950-1980, in the course of 1980-2014 it merely rose by less than one half: $47 \%$ to be exact (Chart 1).

At the same time, the debt raised ten fold in terms of constant prices and the debt-toGDP ratio almost eight fold (Chart 2). The government surpluses and minor deficits of the 1960s and 1970s -minor in relation to the GDP- were followed by ever increasing deficits compared to the GDP, often reaching one fifth the size of the GDP (Chart 3).

A correction was attempted from 1995 onwards, by keeping the debt and deficit at relatively low levels. The debt's parity with the GDP was maintained as long as GDP kept increasing (its growth rate averaged 4.2\% during 2000-2007). Nevertheless, the policy was not sound. As mentioned in the Introduction, it relied almost entirely on domestic private and public consumption. So when consumption decreased due to the advent of the international economic and financial crisis in 2008, and, especially in 2009, tax revenues collapsed, borrowing resumed, the deficit-to-GDP and debt-to-GDP ratios escalated.

Accordingly, creditworthiness declined as it made little market sense to lend a society so that it may go on consuming. Thus the bailout from the IMF, EU and ECB came. We now move on to discuss the reasons the recession was unavoidable, and how the economy may return to a growth path. 
Greek Economy: 1950 - 2014: The 30 Year Road Leading to the Greek Financial Crisis and the IMF-EU-ECB Bail-Out: Investments and Exports Are the Way Out

70

Chart 1. Real GDP and growth rates, 1950 - 2014

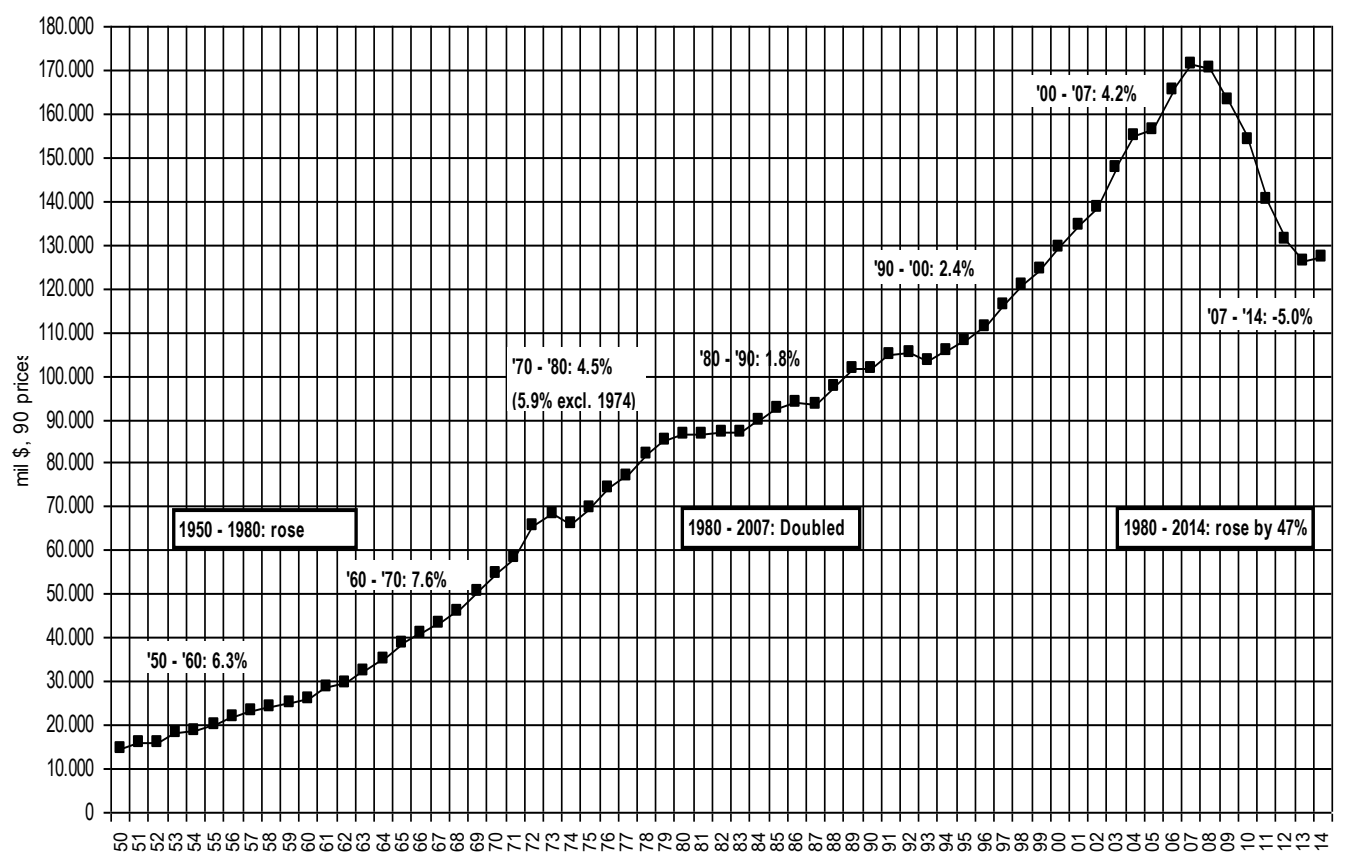

Chart 2. General Government Debt (\% GDP), 1950 - 2014

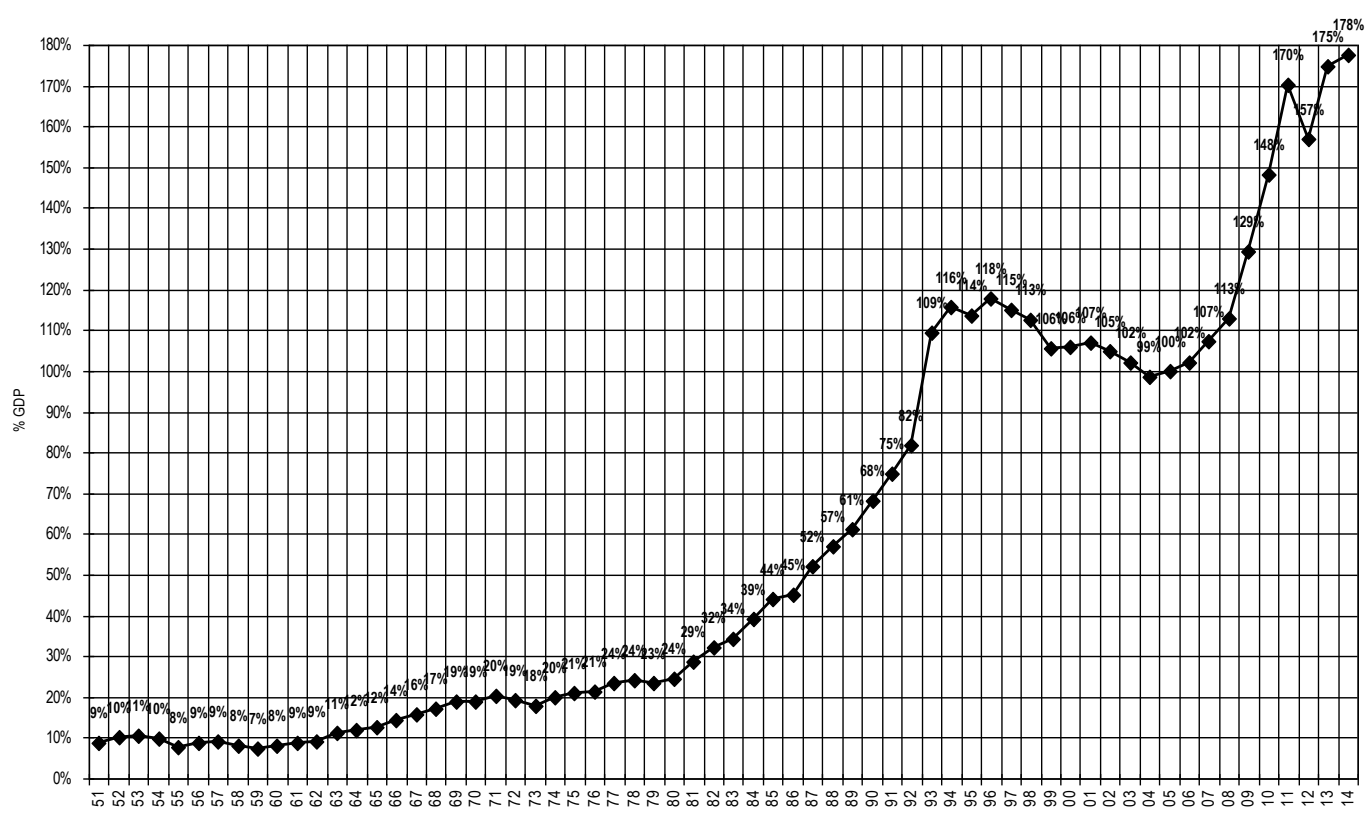


Chart 3. General Government Deficit (\% GDP), 1960 - 2014

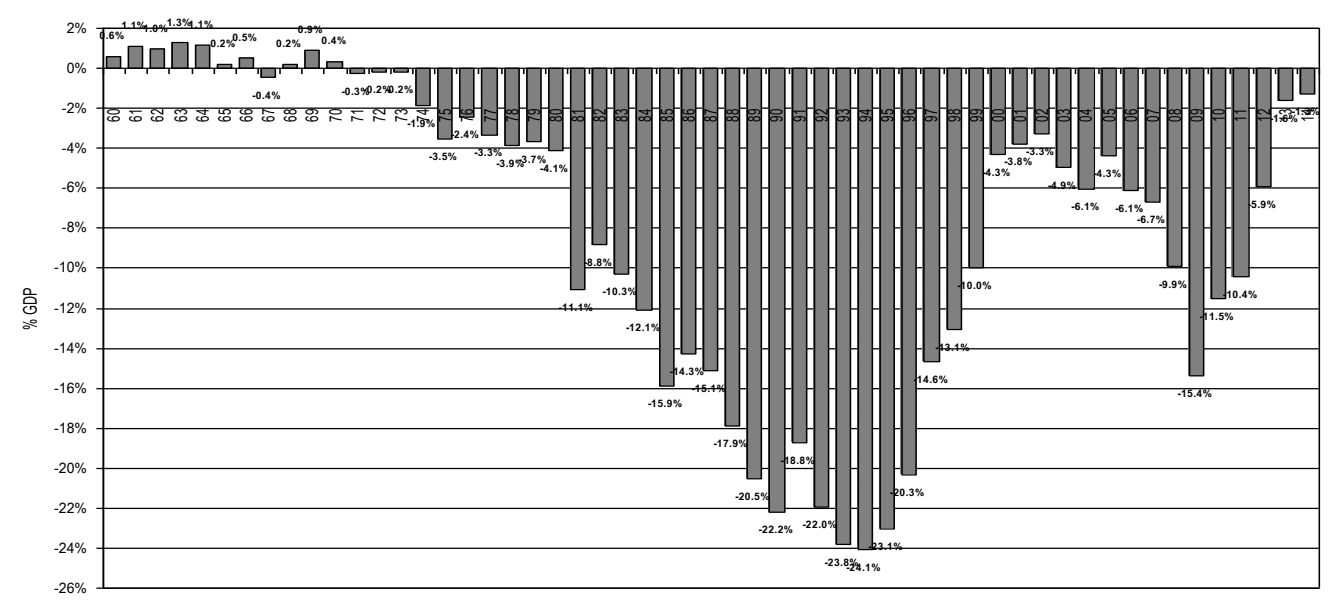

\section{The GDP components and their contribution to growth}

The GDP expression which sums up the economy's expenditures serves as the point of departure:

GDP $=$ Domestic consumption + Investments + Exports - Imports.

The first three components have a positive effect and the fourth a negative effect. As a result, the larger the investments and exports are the brighter the economy's GDP prospects in terms of maintaining positive growth rates.

Next we consider two instances regarding the Greek economy. The Chart 4 tells the story of the economy's fall. Up through the mid-1970s the economy's structure was not only viable, but also showed signs of steady improvement as investments gradually increased to about $40 \%$ of GDP at the expense of consumption. The latter was confined to slightly above $70 \%$ of GDP, which suggests that investment was more than half the share of consumption. By 2009 the situation had changed: was the exact opposite. Investments were low, just $16 \%$ of GDP, while consumption had grown at $95 \%$ of GDP. I.e., investments were only one sixth of consumption. 
Chart 4a. GDP structure of GDP, 1975 and 2009, example of a non- viable economy, Investments account for $1 / 6$ of consumption

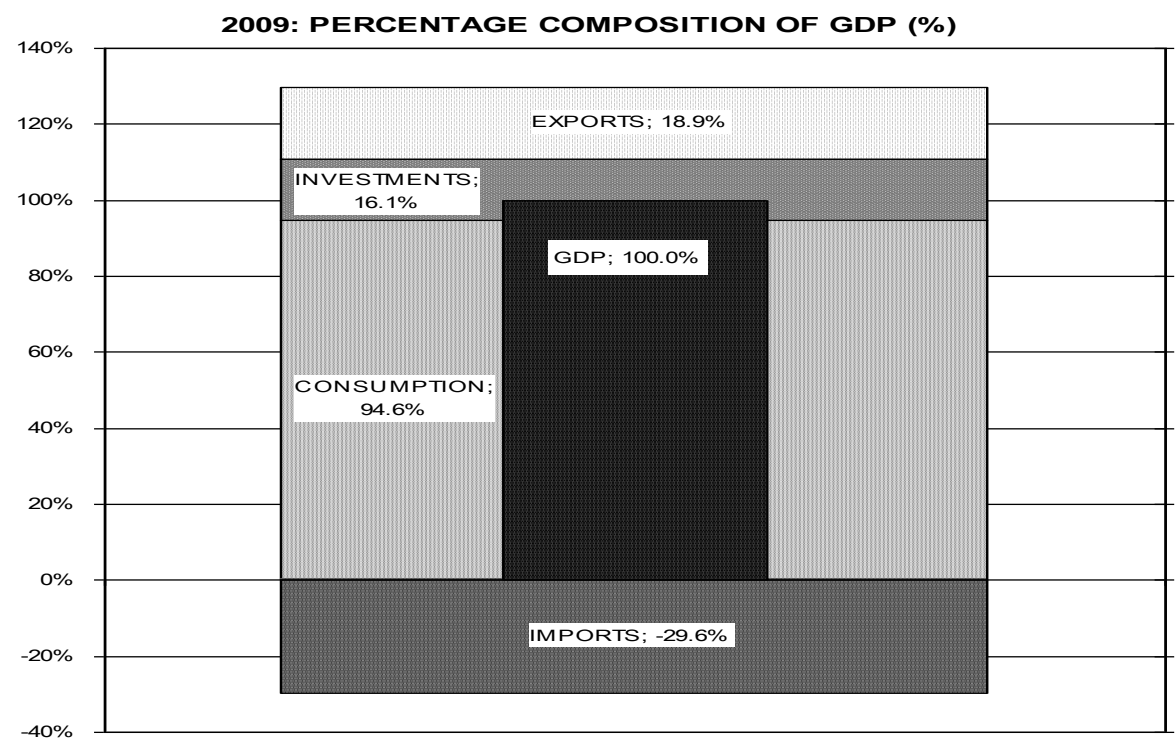

Chart 4b. GDP structure of GDP, 1975 and 2009, example of a viable economy, investments account for over half the consumption

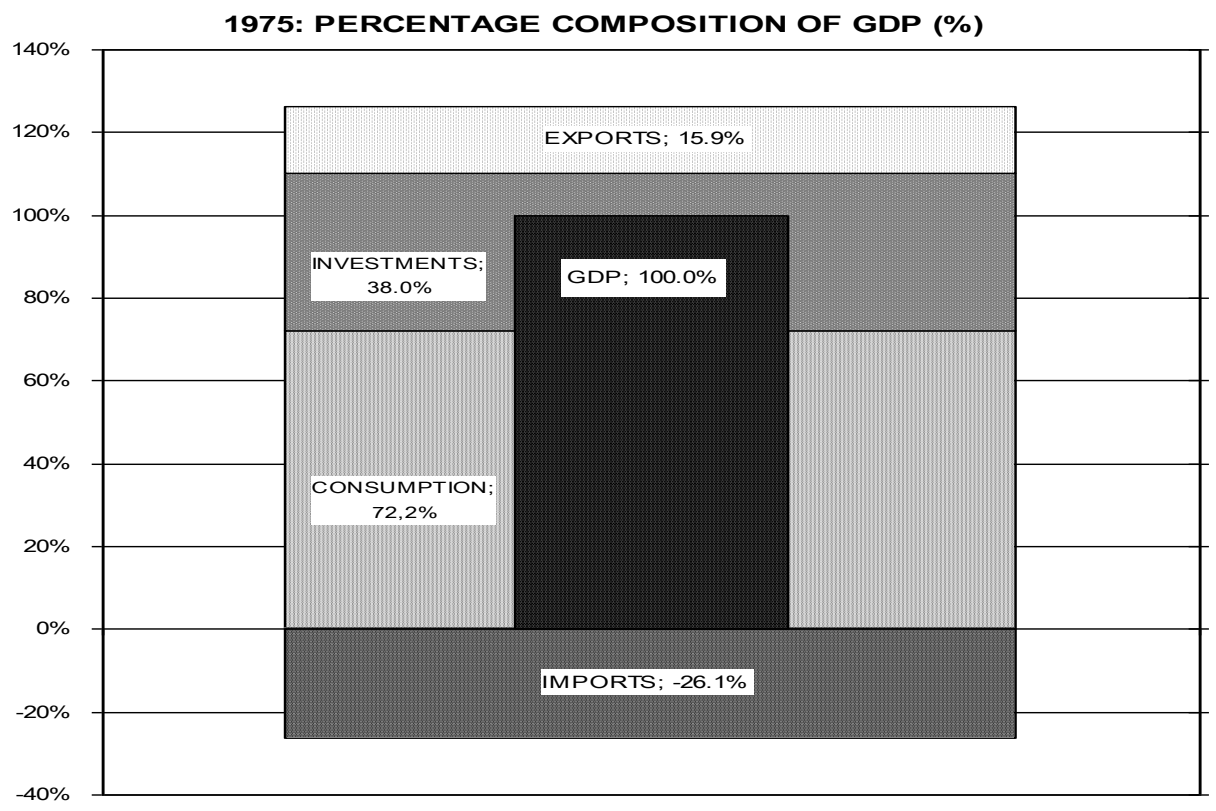


Let us examine GDP changes in 1976 and 2010, respectively. In 1975 the economy grew by $6.5 \%$, while in 2010 it shrunk by $4.5 \%$. Tables $1 \mathrm{~A}$ and $1 \mathrm{~B}$ show the contribution of the four components in overall GDP growth (the contribution of each component is obtained by multiplying its GDP weight times its rate of change). Thus, we may attribute the (a) 1976-GDP growth of $10,2 \%$ to a $(7.3 \% \times 72.2 \%=)$ $5.3 \%$ increase in consumption, a $(8.6 \% \times 38 \%=) 3.3 \%$ increase in investment, a $(10.3 \% \times 15.9 \%=) 1.6 \%$ increase in exports, and a $(14.1 \% \times-26.1 \%=)-3.7 \%$, i.e., a decrease, due to enlarged imports; and (b) 2010-GDP contraction to a $(-4.9 \% \mathrm{x}$ $94.6 \%=)-4.6 \%$ change in consumption, a $(-12.2 \% \times 16.1 \%=)-2 \%$ change in investment, a $(3.8 \times 18,9 \%=) 0.7 \%$ increase in exports, and a $(-4.7 \% \times-29.6 \%=)$ $1.4 \%$ increase due to a decline in imports.

Apparently, the recession may be explained by the drop in consumption which, by 2009, amounted to $95 \%$ of GDP. Likewise, in 2011 the recession was about $7.1 \%$, by and large (i.e., 6.6\%) associated with a further reduction in consumption (by $7.2 \%$ ), with consumption amounting to $91.7 \%$ of GDP. The continued decline in investment by $16.4 \%$ multiplied by its weight $(17.7 \%$ ) added another $-2.9 \%$ to the recession, countered in part by small positive effects associated with exports (a mere $0.1 \%$ due to reduced exports of services) and imports $(2.3 \%$ due to a decline in imports). Again, all these show how vulnerable our economy is and why, under the circumstances, the downturn which occurred was inevitable.

Table 1A. GDP composition (\%) 1975 - 1976

\begin{tabular}{|c|c|c|c|}
\hline GDP Components & $\begin{array}{r}1975 \text { Composition } \\
(\% \text { of GDP })\end{array}$ & $\begin{array}{r}\text { Component } \\
\text { change in } 1976 \\
(\%) \\
\end{array}$ & $\begin{array}{r}\text { Impact of } \\
\text { constituent } \\
\text { components }\end{array}$ \\
\hline Consumption & $72.2 \%$ & $7.3 \%$ & $5.3 \%$ \\
\hline Investments & $38.0 \%$ & $8.6 \%$ & $3.3 \%$ \\
\hline $\begin{array}{l}\text { Exports } \\
\text { - Goods } \\
\text { - Services } \\
\end{array}$ & $\begin{array}{r}\mathbf{1 5 . 9 \%} \\
9.4 \% \\
6.5 \% \\
\end{array}$ & $\begin{array}{r}10.3 \% \\
8.7 \% \\
12.5 \% \\
\end{array}$ & $\begin{array}{l}\mathbf{1 . 6 \%} \\
0.8 \% \\
0.8 \% \\
\end{array}$ \\
\hline $\begin{array}{l}\text { Imports } \\
\text { - Goods } \\
\text { - Services } \\
\end{array}$ & $\begin{array}{r}-26.1 \% \\
-21.6 \% \\
-4.5 \% \\
\end{array}$ & $\begin{array}{l}14.1 \% \\
13.2 \% \\
18.2 \% \\
\end{array}$ & $\begin{array}{l}-\mathbf{- 3 . 7 \%} \\
-2.9 \% \\
-0.8 \% \\
\end{array}$ \\
\hline GDP & $100.0 \%$ & & $+6.5 \%$ \\
\hline
\end{tabular}

Table 1B: GDP composition (\%) 2009 - 2010

\begin{tabular}{|l|r|r|r|}
\hline GDP Components & 2009 Composition & $\begin{array}{r}\text { Component } \\
\text { change in 2010 } \\
(\% \text { of GDP })\end{array}$ & $\begin{array}{r}\text { Impact of } \\
\text { constituent } \\
\text { components }\end{array}$ \\
\hline CONSUMPTION & $94.6 \%$ & $-4.9 \%$ & $-4.6 \%$ \\
\hline
\end{tabular}




\begin{tabular}{|l|r|r|r|} 
INVESTMENTS & $\mathbf{1 6 . 1 \%}$ & $\mathbf{- 1 2 . 2 \%}$ & $\mathbf{- 2 . 0 \%}$ \\
\hline EXPORTS & $\mathbf{1 8 . 9 \%}$ & $\mathbf{3 . 8 \%}$ & $\mathbf{0 . 7 \%}$ \\
- GOODS & $7.9 \%$ & $4.9 \%$ & $0.4 \%$ \\
- SERVICES & $11.0 \%$ & $3.1 \%$ & $0.3 \%$ \\
\hline IMPORTS & $\mathbf{- 2 9 . 6 \%}$ & $-\mathbf{4 . 7 \%}$ & $\mathbf{1 . 4 \%}$ \\
- GOODS & $-24.2 \%$ & $-8.3 \%$ & $2.0 \%$ \\
- SERVICES & $-5.4 \%$ & $11.0 \%$ & $-0.6 \%$ \\
\hline GDP & $\mathbf{1 0 0 . 0 \%}$ & & $-\mathbf{4 . 5 \%}$ \\
\hline
\end{tabular}

\section{The preconditions for returning to economic growth}

The obvious way to return to a growth path is to raise the contribution of exports and investments in the GDP, i.e. to return to the economic structure we had in the past. If and only if these two GDP components grow will GDP figures improve? Indeed, beyond facilitating exports, investments stimulate consumption, which, up until recently relied on borrowing.

Table 2 traces the impact on GDP of hypothetical changes in the four components, initially under the assumption that the GDP is structured as per its 2010-2012 average.

Consider the first scenario: Consumption continues to decrease, say, by $5 \%$, and imports by $2.6 \%$, while exports increase by $6.5 \%$ on account of the encouraging performance of the exported goods and the recent tourist season, and investments by $10 \%$ on account the of privatizations and the attraction of new investors. (A $10 \%$ increase from a starting point of $€ 32$ billion amounts to approximately $€ 3.2$ billion, and corresponds to $18 \%$ of the nominal GDP which currently stands at nearly $€ 180$ billion). In this manner the economy contracts by $0.4 \%$.

The second scenario is more optimistic: Consumption decreases by $4 \%$ (that is a smaller negative effect than before), and imports by $1.6 \%$ (a smaller positive effect), while exports increase by $10 \%$ and investments by $8 \%$. In this case the economy expands by $0.5 \%$.

The third scenario presumes a much healthier initial GDP structure. Investments rise to account for $25 \%$ of GDP, consumption falls to account for $83 \%$ of GDP, while the other two components remain the same. In this case the economy expands by $1.5 \%$. The above show that the transition from economic recession to recovery requires a restructure in which investments and exports increase at the expense of consumption. Understandably, a stable investment environment and the implementation of reforms which are long overdue (namely, a stable tax system, the modernization of the social security and labor system, improving public services and the infrastructure, etc.) in order to attract investments is required. 
Table 2: Scenarios of GDP component evolution (\%)

Example 1

\begin{tabular}{|l|r|r|r|}
\hline GDP Components & $\begin{array}{r}\text { Current } \\
\text { Composition } \\
\text { (\% of GDP) }\end{array}$ & $\begin{array}{r}\text { Hypothetical } \\
\text { component } \\
\text { change } \\
\text { (\%) }\end{array}$ & $\begin{array}{r}\text { Impact of } \\
\text { constituent } \\
\text { components }\end{array}$ \\
\hline CONSUMPTION & $\mathbf{9 0 . 0 \%}$ & $\mathbf{- 5 . 0 \%}$ & $\mathbf{- 4 . 5 \%}$ \\
\hline INVESTMENTS & $\mathbf{1 8 . 0 \%}$ & $\mathbf{1 0 . 0 \%}$ & $\mathbf{1 . 8 \%}$ \\
\hline EXPORTS & $\mathbf{2 3 . 0 \%}$ & $\mathbf{6 . 5 \%}$ & $\mathbf{1 . 5 \%}$ \\
- GOODS & $12.0 \%$ & $7.0 \%$ & $0.8 \%$ \\
- SERVICES & $11.0 \%$ & $6.0 \%$ & $0.7 \%$ \\
\hline IMPORTS & $\mathbf{- 3 1 . 0 \%}$ & $\mathbf{- 2 . 6 \%}$ & $\mathbf{0 . 8 \%}$ \\
- GOODS & $-25.0 \%$ & $-3.0 \%$ & $0.8 \%$ \\
- SERVICES & $-6.0 \%$ & $-1.0 \%$ & $0.1 \%$ \\
\hline GDP & $\mathbf{1 0 0 . 0 \%}$ & & $\mathbf{- 0 . 4 \%}$ \\
\hline
\end{tabular}

Example 2

\begin{tabular}{|l|r|r|r|}
\hline $\begin{array}{l}\text { GDP } \\
\text { COMPONENTS }\end{array}$ & $\begin{array}{r}\text { Current } \\
\text { Composition } \\
(\% \text { of GDP })\end{array}$ & $\begin{array}{r}\text { Hypothetical } \\
\text { component } \\
\text { change } \\
(\boldsymbol{\%})\end{array}$ & $\begin{array}{r}\text { Impact of } \\
\text { constituent } \\
\text { components }\end{array}$ \\
\hline CONSUMPTION & $\mathbf{9 0 . 0 \%}$ & $\mathbf{- 4 . 0 \%}$ & $\mathbf{- 3 . 6 \%}$ \\
\hline INVESTMENTS & $\mathbf{1 8 . 0 \%}$ & $\mathbf{1 0 . 0 \%}$ & $\mathbf{1 . 8 \%}$ \\
\hline EXPORTS & $\mathbf{2 3 . 0 \%}$ & $\mathbf{8 . 0 \%}$ & $\mathbf{1 . 8 \%}$ \\
- GOODS & $12.0 \%$ & $8.0 \%$ & $1.0 \%$ \\
- SERVICES & $11.0 \%$ & $8.0 \%$ & $0.9 \%$ \\
\hline IMPORTS & $\mathbf{- 3 1 . 0 \%}$ & $-1.6 \%$ & $\mathbf{0 . 5 \%}$ \\
- GOODS & $-25.0 \%$ & $-2.0 \%$ & $0.5 \%$ \\
- SERVICES & $-6.0 \%$ & $0.0 \%$ & $0.0 \%$ \\
\hline GDP & $\mathbf{1 0 0 . 0 \%}$ & & $\mathbf{0 . 5 \%}$ \\
\hline
\end{tabular}

Example 3

(if investments reach $25 \%$ of GDP)

\begin{tabular}{|l|r|r|r|}
\hline $\begin{array}{l}\text { GDP } \\
\text { COMPONENTS }\end{array}$ & $\begin{array}{r}\text { Current } \\
\text { Composition } \\
\text { (\% of GDP) }\end{array}$ & $\begin{array}{r}\text { Hypothetical } \\
\text { component } \\
\text { change } \\
(\%)\end{array}$ & $\begin{array}{r}\text { Impact of } \\
\text { constituent } \\
\text { components }\end{array}$ \\
\hline CONSUMPTION & $\mathbf{8 3 . 0 \%}$ & $\mathbf{- 4 . 0 \%}$ & $\mathbf{- 3 . 3 \%}$ \\
\hline INVESTMENTS & $\mathbf{2 5 . 0 \%}$ & $\mathbf{1 0 . 0 \%}$ & $\mathbf{2 . 5 \%}$ \\
\hline EXPORTS & $\mathbf{2 3 . 0 \%}$ & $8.0 \%$ & $\mathbf{1 . 8 \%}$ \\
- GOODS & $12.0 \%$ & $8.0 \%$ & $1.0 \%$ \\
\hline
\end{tabular}




\begin{tabular}{|l|r|r|r|} 
- SERVICES & $11.0 \%$ & $8.0 \%$ & $0.9 \%$ \\
\hline IMPORTS & $\mathbf{- 3 1 . 0 \%}$ & $\mathbf{- 1 . 6 \%}$ & $\mathbf{0 . 5 \%}$ \\
- GOODS & $-25.0 \%$ & $-2.0 \%$ & $0.5 \%$ \\
- SERVICES & $-6.0 \%$ & $0.0 \%$ & $0.0 \%$ \\
\hline GDP & $\mathbf{1 0 0 . 0 \%}$ & & $\mathbf{1 . 5 \%}$ \\
\hline
\end{tabular}

\section{Recent and projected evolutions}

As a confirmation of what has been said in the previous paragraph, let us see what happened in the previous year 2014. Table 3A shows the GDP component evolution in 2014 according to the provisional data of National Accounts. There was a growth of $+0.7 \%$ caused by a slight decrease in consumption $(-0.2 \%)$, a noticeable increase in investment $(+9.9 \%)$, an increase in exports $(+7.5 \%)$ and an increase in imports $(+7.7 \%)$. As a result the positive effects of increased investments and exports $(+3.4 \%)$ exceeded the negative effects from the decline in consumption and the increase in imports $(-2.7 \%)$.

As regards 2015, the picture is still unclear. The latest available national accounts data are for the first half and only the foreign trade data are available for the first eleven months. Therefore, the estimated GDP components changes for 2015 are: consumption and imports decline by $-4 \%$ and $-8.6 \%$, respectively, mainly due to capital controls. Exports show an improvement by $+1.8 \%$ (exports of goods decreased by $-5 \%$ due to the drop in fuel prices, while exports of services grew by $6 \%$ ). Finally, it is estimated that investments will decline by $-8 \%$ due to political instability. These estimates suggest that in 2015 the GDP declined about $-1 \%$ (Table $3 \mathrm{~B}$ ), and show once more the significant effect of investments and exports.

For the coming year 2016 our projections are: Consumption and imports will continue to decline due to capital controls. Exports of goods and services will follow approximately the same trend, while investment will increase mainly due to the ongoing privatization and the restarting of large projects. With these assumptions, GDP will grow about $1 \%$ (Table 3C).

Table 3: Recent and projected GDP component evolutions (\%)

Table 3A: GDP composition (\%) 2013 - 2014

\begin{tabular}{|l|r|r|r|}
\hline GDP Components & $\begin{array}{r}\text { Current } \\
\text { Composition } \\
(\% \text { of GDP })\end{array}$ & $\begin{array}{r}\text { Realized } \\
\text { component } \\
\text { change } \\
(\boldsymbol{\%})\end{array}$ & $\begin{array}{r}\text { Impact of } \\
\text { constituent } \\
\text { components }\end{array}$ \\
\hline CONSUMPTION & $\mathbf{9 1 . 3 \%}$ & $\mathbf{- 0 . 2 \%}$ & $\mathbf{- 0 . 2 \%}$ \\
\hline INVESTMENTS & $\mathbf{1 1 . 5 \%}$ & $\mathbf{9 . 9 \%}$ & $\mathbf{1 . 1 \%}$ \\
\hline EXPORTS & $\mathbf{3 0 . 6 \%}$ & $\mathbf{7 . 5 \%}$ & $\mathbf{2 . 3 \%}$ \\
- GOODS & $16.0 \%$ & $6.9 \%$ & $1.1 \%$ \\
- SERVICES & $14.6 \%$ & $8.2 \%$ & $1.2 \%$ \\
\hline
\end{tabular}




\begin{tabular}{|l|r|r|r|}
\hline IMPORTS & $\mathbf{- 3 3 . 4 \%}$ & $\mathbf{7 . 7 \%}$ & $\mathbf{- 2 . 6 \%}$ \\
- GOODS & $-26.6 \%$ & $8.4 \%$ & $-2.2 \%$ \\
- SERVICES & $-6.8 \%$ & $5.0 \%$ & $-0.3 \%$ \\
\hline GDP & $\mathbf{1 0 0 . 0 \%}$ & & $\mathbf{+ 0 . 7 \%}$ \\
\hline
\end{tabular}

Table 3B: GDP composition (\%) 2014 - 2015 (estimation)

\begin{tabular}{|l|r|r|r|}
\hline $\begin{array}{l}\text { GDP } \\
\text { COMPONENTS }\end{array}$ & $\begin{array}{r}\text { Current } \\
\text { Composition } \\
\text { (\% of GDP) }\end{array}$ & $\begin{array}{r}\text { Estimated } \\
\text { component } \\
\text { change } \\
\text { (\%) }\end{array}$ & $\begin{array}{r}\text { Impact of } \\
\text { constituent } \\
\text { components }\end{array}$ \\
\hline CONSUMPTION & $\mathbf{9 0 . 5 \%}$ & $\mathbf{- 4 . 0 \%}$ & $\mathbf{- 3 . 6 \%}$ \\
\hline INVESTMENTS & $\mathbf{1 2 . 5 \%}$ & $\mathbf{- 8 . 0 \%}$ & $\mathbf{- 1 . 0 \%}$ \\
\hline EXPORTS & $\mathbf{3 2 . 7 \%}$ & $\mathbf{1 . 8 \%}$ & $\mathbf{0 . 6 \%}$ \\
- GOODS & $15.5 \%$ & $-5.0 \%$ & $-0.8 \%$ \\
- SERVICES & $17.2 \%$ & $8.0 \%$ & $1.4 \%$ \\
\hline IMPORTS & $\mathbf{- 3 5 . 7 \%}$ & $\mathbf{- 8 . 6 \%}$ & $\mathbf{3 . 1 \%}$ \\
- GOODS & $-28.7 \%$ & $-9.5 \%$ & $2.7 \%$ \\
- SERVICES & $-7.0 \%$ & $-5.0 \%$ & $0.4 \%$ \\
\hline GDP & $\mathbf{1 0 0 . 0 \%}$ & & $\mathbf{- 0 . 9 \%}$ \\
\hline
\end{tabular}

Table 3C: GDP composition (\%) 2015 - 2016 (projection)

\begin{tabular}{|c|c|c|c|}
\hline $\begin{array}{l}\text { GDP } \\
\text { COMPONENTS }\end{array}$ & $\begin{array}{r}\text { Current } \\
\text { Composition } \\
(\% \text { of } G D P)\end{array}$ & $\begin{array}{r}\text { Projected } \\
\text { component } \\
\text { change } \\
(\%) \\
\end{array}$ & $\begin{array}{r}\text { Impact of } \\
\text { constituent } \\
\text { components }\end{array}$ \\
\hline CONSUMPTION & $90.5 \%$ & $-3.0 \%$ & $-2.7 \%$ \\
\hline INVESTMENTS & $12.5 \%$ & $5.0 \%$ & $0.6 \%$ \\
\hline $\begin{array}{l}\text { EXPORTS } \\
\text { - GOODS } \\
\text { - SERVICES }\end{array}$ & $\begin{array}{l}32.7 \% \\
15.5 \% \\
17.2 \%\end{array}$ & $\begin{array}{r}1.8 \% \\
-5.0 \% \\
8.0 \%\end{array}$ & $\begin{array}{r}\mathbf{0 . 6 \%} \\
-0.8 \% \\
1.4 \%\end{array}$ \\
\hline $\begin{array}{l}\text { IMPORTS } \\
\text { - GOODS } \\
\text { - SERVICES }\end{array}$ & $\begin{array}{r}-35.7 \% \\
-28.7 \% \\
-7.0 \% \\
\end{array}$ & $\begin{array}{l}-6.6 \% \\
-7.0 \% \\
-5.0 \% \\
\end{array}$ & $\begin{array}{l}\mathbf{2 . 4 \%} \\
2.0 \% \\
0.4 \% \\
\end{array}$ \\
\hline GDP & $100.0 \%$ & & $0.9 \%$ \\
\hline
\end{tabular}

Sources : Hellenic Statistical Authority, http://www.statistics.gr, Bank of Greece, http://www.bankofgreece.grl, Eurostat, http://epp.eurostat.ec.europa.eu

\section{Conclusions}

Boosting investments and exports is the only way to bring the country's economy back on a growth path. To that end, regarding exports, a comprehensive, long-term strategic plan aiming to promote high quality products and products of high added 
value to overseas markets is needed. The broad lines of action for the promotion of products of significant importance are the following:

Industrial products: Greece has improved both export performance and presence in international markets in both ttechnology and high-skill-intensive manufactured goods. The presence of a highly educated labor force proficient in new technologies favors the establishment and operation of businesses with such orientation. Thus, a strategy which provides incentives for investing in these sectors will further improve the country's position.

Agricultural products: Greece is a major supplier of many commodities and has a significant presence in foreign markets. Yet, this extrovert position should be strengthened in additional markets and products of high added value. Here, too, we need to adopt strategies and business plans aiming to increase the exports of branded and certified products as opposed to products sold in bulk (olive oil, vegetables, quality wines, dairy products, aromatic and medicinal plants, etc.), and improve the shares of domestically produced goods in international markets in which shares are low (especially in the markets which exhibit dynamism) and enter and actively pursue the markets of rapidly developing nations.

\section{References}

Chalikias J, (2013). Greek Economy 1950 - 2012: How did Greece get into the present economic crisis - Investments and exports are the way out, Greek Economic Outlook, Centre of Planning and Economic Research, No. 22, pp. 44 - 51.

Chalikias J, (2013). The Evolution of Exports of Agricultural Products during the Period 1988 - 2011; Trends, International Competition, Shares in the Foreign Markets, Export Research Center, (Athens).

Chalikias J, (2014). Changes in the Technological Composition of Exported Products of Greece During the Period 1988 - 2013, Export Research Center, (Athens).

Chalikias J, (2014). Disincentives for the Internationalisation of Greek Companies, Export Research Center, (Athens).

Thalassinos, E. and Liapis, K. (2013). A Comparative Analysis for the Accounting Reporting of Employee Benefits between IFRS and other Accounting Standards: A Case Study for the Biggest Listed Entities in Greece. International Journal of Economics and Business Administration, 1(1), 99-124.

Thalassinos, J.E, Hanias, M.P., Curtis, G. (2007). Non-linear dynamics and chaos: The case of the price indicator at the Athens Stock Exchange. International Research Journal of Finance and Economics, 11, 154-63.

Thalassinos, E., Maditinos, D. and Paschalidis, A. (2012). Observing evidence of insider trading in the Athens Stock Exchange. Journal of Economic Structures, 1(1). 